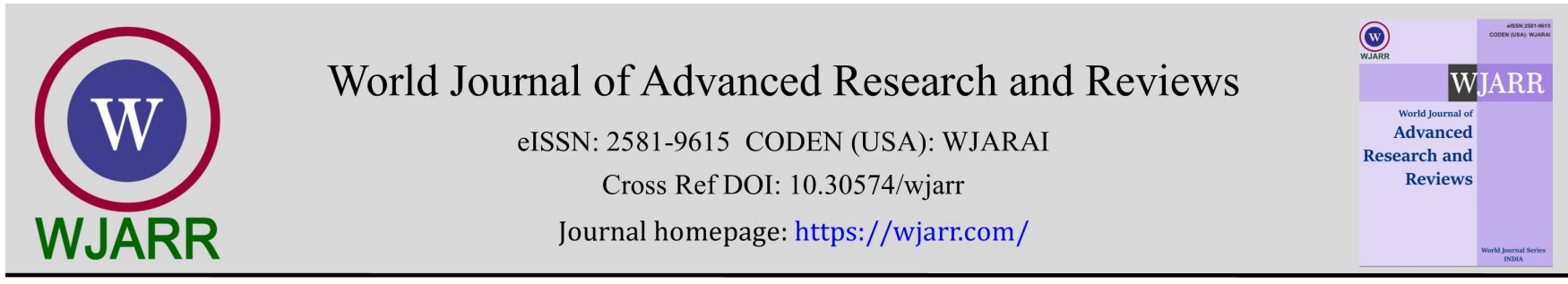

(RESEARCH ARTICLE)

Check for updates

\title{
Radical Scavenging activity and phytochemical screening of the leaf extract of Synsepalum dulcificum (Schumach. \& Thonn.) Daniell
}

\author{
Awotedu BF 1, *, Omolola TO 1, Akala AO 1, Ogunsiji AO 1, Owoeye EA ${ }^{2}$ and Olaoti-Laaro $\mathrm{SO}^{3}$ \\ ${ }^{1}$ Forestry Research Institute of Nigeria, P.M.B 5054, Jericho hills, Ibadan, Oyo State, Nigeria. \\ ${ }^{2}$ Moist Forest Research Station, Benin City, Edo State, Forestry Research Institute of Nigeria. \\ ${ }^{3}$ Forestry Research Institute of Nigeria, Derived guinea savannah research station Ogbomosho, Ibadan, Oyo State, Nigeria.
}

World Journal of Advanced Research and Reviews, 2021, 10(03), 069-076

Publication history: Received on 25 February 2021; revised on 06 June 2021; accepted on 10 June 2021

Article DOI: https://doi.org/10.30574/wjarr.2021.10.3.0241

\begin{abstract}
Antioxidants are chemicals that possess bioactive constituents which usually allow them to fight against free radicals. Antioxidant and phytochemicals properties of the leaves of Synsepalum dulcificum were investigated using ethylacetate, ethanol and methanol extracts. 2, 2-diphenyl-picrylhydrazyl (DPPH) scavenging activity, total antioxidant activity, ferric reducing antioxidant power (FRAP), total flavonoid and the total phenolic content was carried out. The phytochemical screening assay was done on the following: Alkaloids, saponin, flavonoids, tannin, anthraquinones, terpenoids, cardiac glycosides, and phlobatannin using the test solvent extracts. The results gotten for antioxidant revealed that methanol gave the highest extract yield (17.4\%) while ethyl-acetate extract had the least yield (5.0\%). At $250 \mu \mathrm{g} / \mathrm{ml}$ extract concentration, the methanolic extract gave the highest amount with the IC $50 \mathrm{values}(89.94 \mu \mathrm{g} / \mathrm{ml})$, followed by ethanol extract $(68.20 \mu \mathrm{g} / \mathrm{ml}))$ while ethyl acetate extract had the least scavenging activity of $(39.21 \mu \mathrm{g} / \mathrm{ml})$, and these were significantly different $(\mathrm{P}<0.05)$. Total antioxidant activity (ascorbic acid equivalent) at $250 \mu \mathrm{g} / \mathrm{ml}$ of $S$. dulcificum ranged from 41.7 AAE in ethyl-acetate extract to 58.98 AAE in methanol extract. Furthermore, ferric reducing antioxidant power (FRAP) of the leaf extracts revealed that at $250 \mu \mathrm{g} / \mathrm{ml}$ extract concentration, methanol extract had the highest $\left(0.29 \mu \mathrm{molFe}^{2+} / \mathrm{g}\right)$ reduction potential, followed by ethanol extract $\left(0.28 \mu \mathrm{molFe}^{2+} / \mathrm{g}\right)$ and ethyl-acetate extract $\left(0.26 \mu \mathrm{molFe}^{2+} / \mathrm{g}\right)$. The total phenolic content of the extracts ranged from $0.02 \mu \mathrm{g} / \mathrm{ml} \mathrm{TAE}-0.09 \mu \mathrm{g} / \mathrm{ml} \mathrm{TAE}$ at $1000 \mu \mathrm{g} / \mathrm{ml}$ extract concentration while the total flavonoid content ranged from $0.32 \mathrm{mg} / \mathrm{g}$ QE in ethyl-acetate extract to $14.38 \mathrm{mg} / \mathrm{g}$ QE in methanol extract. This study suggests that $S$. dulcificum extract exhibit great potential antioxidant ability that could fight against oxidative stress.
\end{abstract}

Keywords: Synsepalum dulcificum; Antioxidant; Phytochemical; Free radical; Scavengers

\section{Introduction}

Antioxidants are substances that delay or inhibit oxidative damage. They also act as radical scavenger, hydrogen donor, electron donor, peroxide decomposer and singlet oxygen quencher [1]. The main objective characteristic of an antioxidant is its ability to trap free radicals. Antioxidants like phenolic acid, flavonoids and polyphenols scavenge free radicals such as lipid peroxyl, peroxide or hydro peroxide and thus inhibit the oxidative mechanism that leads to degenerative diseases [2]. Oxidative stress is an important risk factor in the pathological process of numerous chronic diseases. Free radicals and other reactive oxygen species are recognized as agents involved in the pathogenesis of diseases such as asthma, inflammatory arthropathies, diabetes, Parkinson's and Alzheimer's diseases, cancer as well as atherosclerosis. Reactive oxygen species are also said to be responsible for human ageing [3-4]. Phytochemicals are known to possess many protective properties which make them vital to both plants and animals. Some of these properties include anti-inflammatory, antioxidant, anti-microbial, antiviral, and anti-carcinogenic properties [5].

\footnotetext{
${ }^{*}$ Corresponding author: Awotedu BF

Forestry Research Institute of Nigeria, P.M.B 5054, Jericho hills, Ibadan, Oyo State. Nigeria.
} 
Synsepalum dulcificum (Schumach. \& Thonn.) Daniell is a plant commonly known as miracle fruit. It is an evergreen shrub of the Sapotaceae family. It originates from West and West-Central tropical Africa. It is about 2-5m (6 to 15 feet) high with the leaves measuring up to $5-10 \mathrm{~cm}$ in length, $2-3.7 \mathrm{~cm}$ in width and are glabrous below. The branches are slender and clustered at the end of the branchlets. The flowers are white with about 2-2.5 cm long fruits and gives red colour when ripe; each fruit contains one seed [6]. The active component present in the berry is the glycoprotein called miraculin which has no taste in itself [7]. When the fruit pulp is licked, it miraculously turns sour foods such as limes, lemons, vinegar etc. consumed to taste sweet because miraculin binds to some receptors on the taste buds to activate the sweet receptors hence resulting in a perception of sweet taste [6]. This action of miraculin is usually favoured at a low $\mathrm{pH}$ (acidic) due to the ingestion of sour food [8], and the effect of the sour food lasts until the protein is washed away by saliva up to about an hour. It is commonly called Agbayun (Yoruba, Nigeria), asowa (Twi, Ghana) and ele (Ewe, Ghana). It has also been found useful and important among diabetics and dieters because studies have shown that the fruit can improve insulin sensitivity [9], and also due to its characteristic of being a low-calorie sweetness enhancer, limiting energy intake [10]. In as much as the fruit act as a taste modifier, the seed, skin and pulp have antioxidant agent which are beneficial to human health [11]. In this research, the study explores the radical scavenging activity and phytochemical screening of the leaf extract of Synsepalum dulcificum.

\section{Material and methods}

\subsection{Sample Collection and Preparation}

This study was carried out at the Forestry Research Institute of Nigeria, Ibadan, and Oyo State, Nigeria. Synsepalum dulcificum leaves were harvested from the plant stands at the plant physiology nursery of the Forestry Research Institute of Nigeria and identified by a taxonomist at the taxonomy section of the Institute. The leaves samples were airdried on a cabinet dryer, milled to powdery form and stored in an airtight container for further analysis.

\subsection{Sample Extraction}

The solvent extraction of each plant sample was prepared by soaking $50 \mathrm{~g}$ of the plant sample in $100 \mathrm{ml}$ of each ethylacetate, ethanol and methanol respectively. These were properly mixed with a shaker for homogeneity and thereafter left for 72 hours (3 days) at ambient temperature. The extracts were obtained by filtration using nest-cloth and the residues were discarded. Each filtrate was then concentrated at reduced pressure using a rotary evaporator. The concentrated extracts were then freeze-dried using a freeze dryer.

\subsection{Antioxidant Activity}

\subsubsection{DPPH Free Radical-Scavenging Activity}

The ability of different solvent (Ethyl-acetate, Ethanol, Methanol) to extracts the leaf of Synsepalum dulcificum and scavenge the DPPH radical was employed using the method described by Mensor et al., [12]. The percentage inhibition of the DPPH radical by the samples was calculated using the following equation:

$$
\% \text { Inhibition }=\frac{(A 0-A 1)}{A 0} \times 100
$$

Where, $A_{0}$ is the absorbance of the control sample and $A_{1}$ is the absorbance of the test sample. The sample concentration providing $50 \%$ of inhibition ( $\mathrm{IC}_{50}$ ) was determined by using several concentrations.

\subsubsection{Ferric Reducing Antioxidant Power Determination (FRAP)}

The ferric reducing capacity of extracts was investigated by using the potassium ferricyanide-ferric chloride method as described by Tundis et al., [13]. Briefly, $0.2 \mathrm{~mL}$ of each of the extracts at different concentrations, $2.5 \mathrm{~mL}$ of phosphate buffer $(0.2 \mathrm{M}, \mathrm{pH} 6.6)$, and $2.5 \mathrm{~mL}$ of potassium ferricyanide $\mathrm{K}_{3} \mathrm{Fe}(\mathrm{CN}){ }_{6}(1 \%)$ were mixed and incubated at $50 \circ \mathrm{C}$ for $20 \mathrm{~min}$, to reduce ferricyanide into ferrocyanide. The reaction was stopped by adding $2.5 \mathrm{~mL}$ of $10 \%$ (w/v) trichloroacetic acid followed by centrifugation at $1000 \mathrm{rpm}$ for $10 \mathrm{~min}$. Finally, $2.5 \mathrm{~mL}$ of the upper layer was mixed with $2.5 \mathrm{~mL}$ of distilled water and $0.5 \mathrm{~mL}$ of $\mathrm{FeCl}_{3}(0.1 \%)$ and the absorbance was measured at $700 \mathrm{~nm}$. The sample concentration providing 0.5 of absorbance ( $\mathrm{IC}_{50}$ ) was calculated by plotting the absorbance against the corresponding sample concentration. BHT and quercetin were used as a reference compound. 


\subsubsection{Determination of Total Flavonoid Content}

Total flavonoid content was measured by the aluminum chloride colorimetric assay of Ordonez et al., [14]. 0.5mL of the extracts or standard solution of quercetin was mixed with $0.5 \mathrm{~mL}$ of $2 \% \mathrm{AlCl} 3$. After 1 hour at room temperature, the absorbance was measured at $420 \mathrm{~nm}$. Total flavonoid content was expressed as microgram quercetin equivalent $(\mu \mathrm{gQE}) / \mathrm{mg}$ dry plant extract.

\subsubsection{Determination of Total Phenolic Content}

The total phenolic content (TPC) was determined spectrophotometrically according to the Folin-Ciocalteu colorimetric method of Arabshahi-Delouee and Urooj, [15]. Briefly, $20 \mu \mathrm{L}$ aliquot of extract solution was mixed with $1.16 \mathrm{~mL}$ of distilled water and $100 \mu \mathrm{L}$ of Folin- Ciocalteu reagent, followed by the addition of $300 \mu \mathrm{L}$ of Na2CO3 solution (20\%). After $30 \mathrm{~min}$ of incubation at $40^{\circ} \mathrm{C}$, the absorbance of the reaction mixture was measured at $760 \mathrm{~nm}$. Gallic acid was used as a reference standard, and the results were expressed as microgram gallic acid equivalent ( $\mu \mathrm{g}$ GAE)/mg dry weight of plant extract.

\subsection{Phytochemical Analysis}

Phytochemical screening of the leaves of $S$. dulcificum was determined using the standard methods previously used by [16-17]. The phytochemicals determined include the following: saponin, alkaloids, tannin, terpenoids, cardiac glycoside, anthraquinones, flavonoids and phlobatannin.

\subsection{Statistical Analysis}

Data were subjected to analysis of variance (ANOVA). Comparison of means was carried out by Duncan's multiple range test. Statistical analysis was performed using the SPSS. Each determination was replicated thrice.

\section{Results and discussion}

The result indicated in Table 1 shows that the percentage yield of the extract obtained from each organic solvent used in the extraction of the leaf of Synsepalum dulcificum. Methanolic extract gave the highest yield of $17.4 \%$, followed by ethanol which gave $7.6 \%$, while the lowest yield was obtained from ethyl-acetate which gave $5.0 \%$

Table 1 Percentage yield of the extract of Synsepalum dulcificum

\begin{tabular}{|l|c|c|c|}
\hline Fraction & Weight of powdered sample (g) & Weight of sample extract (g) & \% Yield \\
\hline Ethyl-acetate extract & 50 & 2.5 & 5.0 \\
\hline Ethanolic extract & 50 & 3.8 & 7.6 \\
\hline Methanolic extract & 50 & 8.7 & 17.4 \\
\hline
\end{tabular}

Table 2 reveals the IC $_{50}$ values of DPPH scavenging activity of the leaf extract of $S$. dulcificum. The scavenging potentials of the three extracts range from $7.12 \%$ in ethyl-acetate extract to $89.94 \%$ in methanol extract. The IC 50 values of methanolic extract have the highest amount which is $89.94 \mu \mathrm{g} / \mathrm{ml}$.

Table 2 The IC50 values of DPPH Scavenging activity of Synsepalum dulcificum leaf extracts

\begin{tabular}{|c|c|c|c|}
\hline $\begin{array}{l}\text { Concentration } \\
(\boldsymbol{\mu g} / \mathbf{m l})\end{array}$ & $\begin{array}{l}\text { \% Scavenging activity of } \\
\text { Ethyl acetate extract }\end{array}$ & $\begin{array}{l}\text { \% Scavenging activity } \\
\text { of Ethanolic extract }\end{array}$ & $\begin{array}{l}\text { \% Scavenging activity } \\
\text { of Methanolic extract }\end{array}$ \\
\hline 50 & $7.12 \pm 0.31 \mathrm{a}$ & $36.22 \pm 1.11 \mathrm{a}$ & $16.22 \pm 0.66 \mathrm{~b}$ \\
\hline 100 & $13.87 \pm 0.81 \mathrm{a}$ & $30.21 \pm 1.08 \mathrm{c}$ & $34.04 \pm 1.32 \mathrm{~b}$ \\
\hline 250 & $39.21 \pm 1.20 \mathrm{a}$ & $68.20 \pm 0.99 \mathrm{~b}$ & $89.94 \pm 2.25 \mathrm{c}$ \\
\hline
\end{tabular}


Table 3 expresses the total antioxidant activity of the leaf extracts of Synsepalum dulcificum with concentration from (5$250 \mu \mathrm{g} / \mathrm{ml}$ ). The result obtained ranges from 18.22 to $58.98 \mathrm{mg} / 100 \mathrm{~g}$ TAAE (ascorbic acid equivalent). The methanolic extract exhibited the highest total antioxidant activity while the least value was recorded in the ethyl-acetate extract.

Table 3 Total antioxidant activity of Synsepalum dulcificum TAAE (ascorbic acid equivalent) mg/100gTAAE

\begin{tabular}{|c|c|c|c|}
\hline Concentration $(\boldsymbol{\mu g} / \mathbf{m l})$ & $\begin{array}{l}\text { Ethyl acetate } \\
\text { extract }\end{array}$ & Ethanolic extracts & Methanolic extracts \\
\hline 5 & $18.22 \pm 0.89 \mathrm{a}$ & $28.0 \pm 1.08 \mathrm{a}$ & $35.51 \pm 1.82 \mathrm{~b}$ \\
\hline 25 & $22.76 \pm 1.64 \mathrm{a}$ & $34.05 \pm 1.32 \mathrm{~b}$ & $41.3 \pm 2.07 \mathrm{c}$ \\
\hline 50 & $33,91 \pm 1.23 \mathrm{~b}$ & $40.66 \pm 1.15 \mathrm{c}$ & $44.91 \pm 1.76 \mathrm{c}$ \\
\hline 100 & $37.59 \pm 1.81 \mathrm{~b}$ & $43.31 \pm 2.08 \mathrm{c}$ & $52.21 \pm 2.31 \mathrm{~d}$ \\
\hline 250 & $41.07 \pm 2.67 \mathrm{c}$ & $51.4 \pm 2.57 \mathrm{~d}$ & $58.98 \pm 2.87 \mathrm{~d}$ \\
\hline \multicolumn{2}{|r|}{ Mean values with similar superscript in a column are not significantly different (P>0.05) } \\
\hline
\end{tabular}

Table 4 reveals the Ferric Reducing Antioxidant Power (FRAP) of the leaf extracts of S. dulcificum using different solvents with different concentration. The values ranged from $0.14 \mu \mathrm{mol} \mathrm{Fe} \mathrm{Fe}^{2+} / \mathrm{g}$ in ethyl-acetate extract to $0.29 \mu \mathrm{molFe}^{2+} / \mathrm{g}$ in methanolic extract.

Table 4 Ferric reducing antioxidants power (FRAP) of Synsepalum dulcificum leaf extracts $\left.\left(\mu \mathrm{molFe}{ }^{2+}\right) / \mathrm{g}\right)$

\begin{tabular}{|c|c|c|c|}
\hline Concentration $\boldsymbol{\mu g} / \mathbf{m l}$ & Ethyl acetate extract & Ethanolic extract & Methanolic extract \\
\hline 5 & $0.14 \pm 0.00 \mathrm{a}$ & $0.21 \pm 0.00 \mathrm{a}$ & $0.23 \pm 0.00 \mathrm{~b}$ \\
\hline 25 & $0.16 \pm 0.00 \mathrm{a}$ & $0.23 \pm 0.00 \mathrm{a}$ & $0.24 \pm 0.01 \mathrm{~b}$ \\
\hline 50 & $0.21 \pm 0.00 \mathrm{a}$ & $0.25 \pm 0.00 \mathrm{~b}$ & $0.26 \pm 0.00 \mathrm{c}$ \\
\hline 100 & $0.24 \pm 0.01 \mathrm{a}$ & $0.25 \pm 0.00 \mathrm{~b}$ & $0.28 \pm 0.01 \mathrm{c}$ \\
\hline 250 & $0.26 \pm 0.01 \mathrm{a}$ & $0.28 \pm 0.01 \mathrm{~b}$ & $0.29 \pm 0.01 \mathrm{c}$ \\
\hline
\end{tabular}

The total flavonoid content of the leaf extract of $S$. dulcificum using different solvent at different concentrations is shown in Table 5. Total flavonoid content result shows that at $500 \mathrm{mg} / \mathrm{g}$; ethyl-acetate possess the least value $(-0.22 \mathrm{mg} / \mathrm{g})$, followed by ethanol extract $(3.10 \mathrm{mg} / \mathrm{g})$ and the highest value was methanol $(6.89 \mathrm{mg} / \mathrm{g})$. Also at $1000 \mathrm{mg} / \mathrm{g}$, ethylacetate possess the least value $(0.32 \mathrm{mg} / \mathrm{g})$, followed by ethanol extract $(7.25 \mathrm{mg} / \mathrm{g})$ and the highest value which is methanol has $(14.38 \mathrm{mg} / \mathrm{g})$.

Table 5 Total flavonoid content of Synsepalum dulcificum leaf extracts

\begin{tabular}{|c|c|c|}
\hline \multirow[t]{2}{*}{ Extracts } & \multicolumn{2}{|c|}{ Total flavonoid (mg/gqe) } \\
\hline & $500 \mathrm{mg} / \mathrm{g}$ & $1000 \mathrm{mg} / \mathrm{g}$ \\
\hline Ethyl acetate & $-0.22 \pm 0.43 a$ & $0.32 \pm 0.09 a$ \\
\hline Ethanol & $3.10 \pm 0.23 b$ & $7.25 \pm 1.26 b$ \\
\hline Methanol & $6.89 \pm 1.02 c$ & $14.38 \pm 1.68 c$ \\
\hline
\end{tabular}

Total phenolics content of the leaf extract of $S$. dulcificum using different solvent at different concentrations is shown in Table 6. Total phenolics content result shows that at $500 \mathrm{mg} / \mathrm{g}$; ethyl-acetate possess the least value $(0.01 \mathrm{mg} / \mathrm{g})$, followed by ethanol extract $(0.02 \mathrm{mg} / \mathrm{g})$ and the highest value was methanol $(0.04 \mathrm{mg} / \mathrm{g})$. Also at $1000 \mu \mathrm{g} / \mathrm{ml}$, ethylacetate possess the least value $(0.02 \mu \mathrm{g} / \mathrm{ml})$, followed by ethanol extract $(0.07 \mu \mathrm{g} / \mathrm{ml})$ and the highest value which is methanol has $(0.09 \mu \mathrm{g} / \mathrm{ml})$. 
Table 6 Total phenolic content of Synsepalum dulcificum leaf extracts

\begin{tabular}{|l|c|c|}
\hline \multicolumn{1}{|c|}{ Extracts } & \multicolumn{2}{|c|}{ Total Phenolics $(\boldsymbol{\mu g} / \mathbf{m l t a e})$} \\
\hline & $500 \mathrm{mg} / \mathrm{g}$ & $1000 \mu \mathrm{g} / \mathrm{ml}$ \\
\hline Ethyl acetate & $0.01 \pm 0.00 \mathrm{~b}$ & $0.02 \pm 0.00 \mathrm{~b}$ \\
\hline Ethanol & $0.02 \pm 0.04 \mathrm{c}$ & $0.07 \pm 0.01 \mathrm{c}$ \\
\hline Methanol & $0.04 \pm 0.00 \mathrm{a}$ & $0.09 \pm 0.00 \mathrm{a}$ \\
\hline
\end{tabular}
* Mean values with similar superscript in a column are not significantly different $(\mathrm{P}>0.05)$

The result of the qualitative preliminary assessment for phytochemicals of the solvent extractions of $S$. dulcificum is expressed in Table 7: The result shows that phytochemicals are present in the leaves of S. dulcificum. The phytochemicals present in all the extracts include alkaloids, flavonoid, saponins and tannin. Terpenoids, cardiac glycosides, anthraquinone and phlobatannin are absent in ethyl-acetate extract and ethanolic extract. Terpenoids and cardiac glycosides are present in methanol extract while anthraquinones and phlobatannin are absent.

Table 7 Phytochemical screening of the leaves of Synsepalum dulcificum

\begin{tabular}{|l|c|c|c|}
\hline Phytochemical & Ethyl-acetate Extract & Ethanolic Extract & Methanolic Extract \\
\hline Alkaloid & + & + & + \\
\hline Flavonoid & + & + & + \\
\hline Saponin & + & + & + \\
\hline Tannin & + & - & + \\
\hline Terpenoids & - & - & + \\
\hline Cardiac Glycosides & - & - & - \\
\hline Anthraquinones & - & - & - \\
\hline Phlobatannin & - & \multicolumn{2}{|c|}{} \\
\hline
\end{tabular}

\section{Discussion}

\subsection{Antioxidant Activity}

Antioxidant substance gives protection to the body from damages caused by free radical-induced oxidative stress. The result indicated from the research shows that the potential of the methanol extract of $S$. dulcificum leaf to scavenge free radicals is higher compared to Dada, [18] who reported the scavenging ability of Uzazi leaf extract that ranges from $43.99 \%-73.87 \%$. The antioxidant as a radical scavenger donates a proton to the mobile radicals in the body which in turn decrease the absorption of radical scavenging activity in the human body [19]. Thus, the changes in the coloration of the solution indicate the scavenging potential of the antioxidant. This result is a pointer that the consumption of the miracle fruit leaf extract may fight against the free radicals present in the body which are produced during respiration and other body metabolism. The total antioxidant activity obtained in this study is on the high side compared with the extract of Chysophyllum albidum which ranged from 21.33-50.6 mg/100g TAAE in the research reported by Oguntoyinbo et al., [20]. On the contrary, in this research, methanol extract gave the highest antioxidant activity while in the research of Oguntoyinbo et al., [20] ethanol extract gave the highest. The result gotten by Pracheta et al., [21] reveals that the total antioxidant activity of the leaf extract of Cynara scolymus ranges from 18.17 to 50.38 mg/100GTAAE which are a bit lower than that reported in this study. The antioxidant capacity of all the extracts increases with the concentration increase. There was a significant difference $(p>0.05)$ in the antioxidant activity of all the extract and the difference varies across some of the concentrations. The total antioxidant activity of plant extracts explains its scavenging potential against free radicals. This shows that the leaf extracts of Synsepalum dulcificum possess antioxidant properties and according to Tawheed and Monika, [22] who states that the antioxidant ability of leaf extracts helps to stabilize the integrity of the cell membrane. The ferric reducing antioxidant content (FRAP) of $S$. dulcificum was quite low compared to the value reported by Pracheta et al., [21] who reported $0.88 \mu \mathrm{molFe} \mathrm{F}^{2+} / \mathrm{g}$ to 3.36 
$\mu \mathrm{molFe} \mathrm{F}^{2+} / \mathrm{g}$ for Cynara scolumus. The antioxidant potential of the leaf extract of $S$. dulcificum was estimated from their ability to reduce TPRZ Fe ${ }^{3+}$ complex to TPTZ $\mathrm{Fe}^{2+}$ at $593 \mathrm{~nm}$ and its antioxidant activity increased proportionally with the polyphenol content. Thus, leaf extracts act as free radical scavenger, capable of transforming reactive free radical species into stable non-radical products. Total flavonoid content of the leaf extract of $S$. dulcificum was quite high compared to $1.79 \mathrm{mg} / \mathrm{gQE}$ reported for Euphorbia neriifolia leaf extract by Pracheta et al., [21]. The result gotten in the study is comparably higher compared to that reported by Oguntoyinbo et al., [20] for Chrysophyllum albidum leaf extract. Flavonoids are free scavenging radicals that also double as water-soluble antioxidants usually prevent oxidative cell damage, anticancer and antitumor growth [22]. The total phenolic content of S. dulcificum leaf extracts $(0.01 \mu \mathrm{g} / \mathrm{mlTAE}-$ $0.09 \mu \mathrm{g} / \mathrm{mlTAE}$ ) is within the same range as that reported for extracts of Chrysophyllum albidum in the report of [20] (Oguntoyinbo et al., 2015). Plants that contain phenolic compounds indicate that such plant possesses antioxidant and antimicrobial activity [23]. They also serve in plant mechanisms to counteract reactive oxygen species (ROS) in other to prevent molecular damage [24]. The presence of phenolic compounds in the plant part may indicate that S. dulcificum contains antimicrobial agents. According to Memnune et al., [23], the extracts may possibly contain different type of phenolic compounds, which have different antioxidant capacities. Phenolic compounds add to the coloration, taste, aroma and flavor. It also helps in providing health beneficial effects. They also serve in plant mechanisms to counteract reactive oxygen species (ROS) in other to prevent molecular damage [24].

\subsection{Phytochemical screening}

Plants always contain some active substances that have been widely reported to contribute their metabolic, physiologic and protective effects to humans [25]. The result gotten in this study shows all the solvent extract (ethyl-acetate, methanol and ethanol) were able to extract alkaloid, flavonoid, saponin and tannin. The result obtained in this study corroborates the one reported for Leea guineensis leaves by Awotedu et al., [26]. It is also in line with the one reported for other plants by Oyeyemi et al., [27]. Alkaloids have been known to possess antihypertensive, anti-inflammatory, antifungal, antifibrogenic and microbiocidal effect [28]. Alkaloid present in this study also aligns with the work reported by Awoyinka et al., [29] who also reveals that alkaloid is present in Cnidoscolus aconitifolius. Alkaloids are beneficial chemicals to plants, serving as a repellent to predators and parasites. The presence of alkaloids in the leaves of this plant may be responsible for its antimalaria effect, possession of analgesic properties and its use in the treatment of stomach disorder [30]. Tannins are reported to serve as antidotes for many poisons [31], antibacterial [32], and anti-parasitic [33] and also they can help in the protection of the kidney. Therapeutically, when tannin is present in plants, it cures diverse range of diseases. Ijoma et al., [34] reported the presence of tannin in Dialium indium leaves which is synonymous with our findings. Hence, the presence of tannin in this study makes the plant a useful source of antidotes for poisons and serves as immediate relief for people with sore throat, diarrhea and dysentery and wounds [35]. Saponin produced by plant always fight infections produced by parasites. When saponin is taken by human beings, it helps the body system to fight against viruses and bacteria. However, the occurrence of saponin in this study suggests it for use in fighting against infections and recommending it for soap making properties because of its foamy abilities. Flavonoids which are widely distributed in plants are known to exert multiple biological effects including antioxidant, free radical scavenging, anti-inflammatory and anti-carcinogenic effects. They also prevent oxidative cell damage and have strong anti-cancer activity. Flavonoid in intestinal tracts lowers the risk of heart disease [19]. The biological function of flavonoids includes protection against allergies, inflammatory, free radical scavenging, and platelets aggregation [3630]. This may account for the natural antioxidant properties of the flavonoids by acting against oxidative stress-related diseases such as diabetics, cancer and coronary heart disease [37]. Hence, people that are prone to such diseases can feed on S. dulcificum plant as a source of natural antioxidants. The presence of flavonoids in plants at times generally serves as flavouring agents [38]. Methanol is the only solvent that extracted cardiac glycoside while it is absent in other solvents. Cardiac glycosides had been reported to be effective in the treatment of congestive heart failure and regulation of heartbeat [39]. Hence, the presence of these phytochemicals in S. dulcificum leaves tend to support its medicinal use.

\section{Conclusion}

The crude extracts of the leaf of Synsepalum dulcificum were found to possess radical scavenging and phytochemical potentials. We may conclude that methanol and ethanol extracts exhibited better antioxidant activities compared to ethyl-acetate extract. These results indicate that Synsepalum dulcificum leaf could be an accessible source of natural antioxidant agent that could combat various kinds of human diseases and could also help in the treatments of arrays of ailments and diseases. 


\section{Compliance with ethical standards}

\section{Acknowledgement}

I sincerely appreciate the effort of my research colleagues at Forestry Research Institute of Nigeria that contributed in one way or the other to the success of this research work.

\section{Disclosure of conflict of interest}

The authors declare that they have no competing interests.

\section{References}

[1] Yamagishi S, Matsui T. Nitric oxide, a Janus-faced therapeutic target for diabetic microangiopathy-Friend or foe? Pharmacol Res. 2011; 64: 187-194.

[2] Wu YY, Li W, Xu Y, Jin EH, Tu YY. Evaluation of the antioxidant effects of four main theaflavin derivatives through chemiluminescence and DNA damage analyses. J Zhejiang Univ Sci B. 2011; 12: 744-751.

[3] Kanwar JR, Kanwar RK, Burrow H, Baratchi S. Recent advances on the roles of NO in cancer and chronic inflammatory disorders. Curr Med Chem. 2009; 16: 2373-2394.

[4] Chiavaroli V, Giannini C, De Marco S, Chiarelli F, Mohn A. Unbalanced oxidant-antioxidant status and its effects in pediatric diseases. Redox Rep. 2011; 16: 101-107.

[5] Leverin G, McMatron H. Alkaloids and glycosides. Clin. Microbiol. Rev. 1999; 11: 156-50.

[6] Achigan-dako EG, Tchokponhoue DE, Sognigbe N, Gebauer J, Vodouhe RS. Current knowledge and breeding perspectives for the miracle plant Synsepalum dulcificum (Schum. \& Thonn.) Daniell. Genet Resource Crop Evolution. 2015; 62(1): 465-476.

[7] Chen CY, Wang YD, Wang HM. Chemical constituents from the leaves of Synsepalum dulcificum. Chem. Nat Compounds. 2010; 46(3): 495.

[8] Koizumi A. Human sweet taste receptor mediates acid-induced sweetness of miraculin. Proceedings of the National Academy of Sciences. 2011.

[9] McCurry J. Miracle berry lets Japanese dieters get sweet from sour. London: The Guardian. 2005.

[10] Wong JM, Kern M. Miracle fruit improves sweetness of a low-calorie dessert without promoting subsequent energy compensation. Appetite. 2011; 56(1): 163-166.

[11] Inglett GE, Chen D. Contents of phenolics and flavonods and antioxidant activities in skin, pulp, and seeds of miracle fruit. J. of Food Sci. 2011; 76(3): 479-481.

[12] Mensor LL, SM Fabio, GL Gildor, SR Alexander, CD Tereza, SC Cintia, GL Suzane. Screening of Brazilian plant extracts for antioxidant activity by the use of DPPH free radical methods. Phytother. Res. 2001; 15: 127-130.

[13] Tundis R, Menichini F, Bonesi M, Conforti F. Antioxidant and hypoglycaemic activities and their relationship to phytochemicals in Capsicum annuum cultivars during fruit development. LWT-Food Science and Technology, 2013; 53(1): 370-377.

[14] Ordonez AAL, Gomez JD, Vattuone MA, Isla MI. Antioxidant activities of Sechiumedule (Jacq.) Swartz extracts, Food Chemistry. 2006; 97(3): 452-458.

[15] Arabshahi-Delouee S, Urooj A. Antioxidant properties of various solvent extracts of mulberry (Morus indica L.) leaves, Food Chemistry. 2007; 102(4): 1233-1240.

[16] Boye AG, Koffuor GA, Boampong JN, Amoateng PA, Ameyaw EO, Ansah EO, Addai GM, Adjei CK, Addo J, Penu D. KA. Gastroprotective effect and safety assessment of Zanthoxylum zanthoxyloides (Lam) Waterm root bark extract'. American Journal of Pharmacy and Toxicology. 2012; 7(2): 73-80.

[17] Omoruyi BE, Bradley G, Afolayan AJ. Antioxidant and phytochemical properties of Carpobrotus edulis (L.) bolus leaf used for the management of common infections in HIV/AIDS patients in Eastern Cape Province. BMC Complementary and Alternative Medicine. 2012; 12: 215. 
[18] Dada AA. The antioxidant and antimicrobial activities of some spices. Unpublished Department of Food Science and Technology, Federal University of Technology, Akure, Ondo State Nigeria. 2010; 31-40.

[19] Orijajogun OJ, Olajide O0, Fatokun AO, Orishadipe AY, Batari ML. The preliminary chemical constituent of free radical scavenging activity of the exocarp of the fruit extract of African star apple (Chrysophllum Albidum). International Journal of Pharma Science and Research. 2013; 3(3): 72-80.

[20] Oguntoyinbo 00, Abdus-Salaam RB, Bello WA, Ifesan BOT. Evaluation of the phytochemical, antioxidant and antimicrobial properties of extracts from Chrysophyllum albidum (African Star Apple) leaf. Journal of Food Technology Research. 2015; 2(1): 1-10.

[21] Pracheta VS, Ritu P, Sadhana S. In vitro free radical scavenging and antioxidant potential of ethanolic extract of Euphorbia neriifolialinn. International Journal of Pharmacy and Pharmaceutical Science. 2010; 3: 238-242.

[22] Tawheed A, Monika T. A comparative study on proximate composition, phytochemical screening, antioxidant and antimicrobial activities of Linum usitatisimum L (Flax Seeds). International Journal of Current Microbiology and Applied Sciences. 2014; 3(4): 465-481.

[23] Memnune S, Hilal Y, Neva G, Bulent C, Zeynep B, Sezai B. Total phenolic content, antioxidant and antimicrobial activities of some medicinal plants. J. Analytical Chemistry. 2009; 22: 102-109.

[24] Abiodun HA, Amos OA, Rosline K, Olayemi OA, Olorunfemi TB, Taiwo OS. Antioxidant activities of the leaves of Chrysophyllum albidum. Pak. J. Pharm. Sci. 2011; 24(4): 545-551.

[25] Edeoga HO, Eriata DO. Alkaloid, tannin and saponin contents of some medicinal plants. Journal of Medicinal Aromatic Plant Science. 2001; 23(3): 344-349.

[26] Awotedu OL, Ogunbamowo PO, Emmanuel IB, Lawal IO. Phytominerals and phytochemical studies of Azadiracthta indica, Leea guineensis and Parkia biglobosa leaves. International Annals of Science. 2019; 6(1): 2834.

[27] Oyeyemi SD, Arowosegbe S, Adebiyi AO. Phytochemical and proximate evaluation of Myrianthus arboreus (P. Beau.) and Spargonophorus sporgonophora (Linn.) leaves. IOSR Journal of Agriculture and Veterinary Science. 2014; 7(9): 01-05.

[28] Ghoshal S, Krishna BN, Lakshmi V. Antiamoebic activity of piper longum fruits against Entamoeba histolytica in vito and in vivo. Journal of Ethnopharmacology. 1996; 50: 167-170.

[29] Awoyinka AO, Balogun IO, Ogunnowo AA. Phytochemical screening and in-vitro bioactivity of Cnidoscolus aconitiifolus (Euphorbiaceae). Journal of Medicinal Plants Research. 2007; 1(3): 63-65.

[30] Okwu DE, IN Emenike. Evaluation of the phyto-nutrients and vitamins content of the citrus fruits. International Journal of Molecular Medicine and Advance Science. 2006; 2(1): 1-6.

[31] Norton BW. The significance of tannins in tropical animal production. Tannins in livestock and human nutrition. ACIAR Proceedings. 2000; 92: 14-22.

[32] Akiyama H, Kazuyasu F, Yamasaki O, Oono T, Iwatsuki K. Antibacterial action of several tannins against Staphylococcus aureus. Journal of Antimicrobial Chemotherapy. 2001; 48: 487-491.

[33] Kolodziej H, Kiderlen AF. Antileishmanial activity and immune modulatory effects of tannins and related compounds on Leishmania parasitised RAW 264.7 cells. Phytochemistry. 2005; 66: 2056-2071.

[34] Ijoma KI, Ajiwe VIE. Phytochemical Screening of Dialium Indum Leaf extract (Velvet Tarmarind) International Journal of Phytopharmacy. 2017; 7(1): 06-13.

[35] Okwu DE. Phytochemicals and vitamin content of indigenous spices of South-eastern Nigeria. Journal of Sustainable Agriculture and Environment. 2004; 6: 30-34.

[36] Okwu DE, OD Omodamiro. Effect of hexane extract and phytochemical content of xylopia aethiopica and ocimum gratissium on uterus of Guinea pig. Bioresearch. 2005; 3(2): 40-44.

[37] Bunt M, F Bucar. Antioxidant activity of Nigella sativa essential oils. Phytochemistry. 2000; 57: 99-102.

[38] Kujumgiev A, Tsevetkova I, Serkedjivay Y, Bankova V, Christov R, Popov S. Antibacterial, antifungal and antiviral activity of Propolis of different geographic origin. Journal of Ethnopharmacology. 1999; 44: 35-40.

[39] Silva E, Soares-da-Silva P. New Insights into the Regulation of Na b, K p -ATPase by Ouabain. 2012; 294: 99-132. 